\title{
Inquiry on the Personnel Training Mode of Preschool Education Major Under the Background of Supply-side Reform
}

\author{
An Hongtao ${ }^{1}$ * \\ ${ }^{1}$ Zaozhuang University, Zaozhuang, Shandong Province 277160, China \\ *email: anhongtao2004@163.com
}

Keywords: educational supply-side reform, personnel training mode, preschool education.

\begin{abstract}
With the progress of preschool education, the requirements of society in preschool education teachers have changed greatly from quantity to quality. Facing the new situation of the demand side, the colleges and universities need to improve some malpractices, such as inefficient school running, relatively closed school-running mode, and graduates' weak social adaptation ability. So with the supply-side reformation on personnel training mode of preschool education major, the action-oriented curriculum system, optimization of the course content and the talent training with innovation spirit, the development of preschool education career will be actuated. If that, we can have more and more preschool teachers with experting in one thing and good at many.
\end{abstract}

\section{Introduction}

"National medium and long-term plan for education reform and development (2010-2020)"put forward clearly the planning goal in the effort to make preschool education basically, that by 2020 , roundly universal access to popularize one year preschool education, basically universal access to two years preschool education, and universal access to three years in some areas.

Though, the recruitment scale of preschool education major is enlarged gradually, local colleges and universities are usually faced with some malpractices, such as inefficient school running, relatively closed school-running mode, and graduates' weak social adaptation ability. It is precisely because of low efficiency of the supply that the society suffers from the "labor shortage" and "employment difficulty" at the same time.

\section{The Severe Challenges Faced with the Graduates in Pre-school Education Major}

Firstly, though the staffing of kindergartens is relative stable, the competition is stiff. So, it means admitting that we have been wrong, that after being employed the graduates attend training. The graduates have to complete the transition from profession to occupation during the study period.

Secondly, with the social guide of the promotion in the preschool educational quality, the employers have higher requirement in the professionalism and competency of the graduates.

Thirdly, with the impetus of the public policy, all kinds of educational organizations for young children have been improved a lot. The demand for talent is more various, relative to public education institutions. The requirement of professionalism is more constructive. All the situations force us to think how to afford more affluent means of employment with so enormous job market. 
Fourthly, newly-upgraded local universities have been transformed. The education majors are faced with many limitations, relative to the rapid transformations of science and technology subject. It is urgent to be solved that the preschool education major changes challenges into opportunities faced with the resource reorganization.

Finally, teachers' certification system have important adjustment and change. Teachers' qualification examinations are uniformly organized by the state, to realize a more complete perspective of kindergarten teachers' professionalism.

The colleges and universities are in supply-side of labor market. And, it must adjust teaching aim, reform in teaching and curriculum system, according the tendency of our country's development of early childhood education, utilizing the available resources and vocation, reflecting special features. Then, walking the developing road specializing the preschool education major will have a situation of integration in theory, ability and quality. It can progress the personalized improvement of students. The construction of teaching staff will be more aligned with orientation of running colleges. Practice teaching will be strengthened immensely and benefit the training of professional ability.

\section{Ways of Pre-school Education Major Reformation}

In truth, donating to charity, the core reformation of the supply side is deregulation, releasing energy and let the market playa bigger role, consequently reduce institutional transaction cost and promote quality and efficiency of supply-side. As the main supplier of local preschool education, application-oriented university needs necessarily to think over and tackle this question about three aspects, that to integrate existing school and social resources and make it play a role of actual; to survey the market demands, and enlarge the direction of talent training; to provide continuing education services face to the society.

\subsection{Create Oriented Personnel Training Program with Innovation and Development Ability}

Corresponding with the demands of the times, we should create personnel training program based on the reform of preschool education and social development, and cultivate special talents who have teachers' career consciousness and development ability. In that way, graduates will have more kinds of professional skills, be quite qualified for kindergarten, early education organization, education management department, preschool education consultation organization and so on.

Ministry of education "about some ideas improving higher vocational education quality of teaching all rounds" is the programmatic document guiding universities and colleges teaching to work. For example, in Zaozhuang University requirements for pre-school education major at undergraduate level is 160 Credits and 2600 class hours at most. The undergraduate curriculum includes general course, subject curriculum and specialized courses. In terms of share of class hours, practice oriented courses is accounted for $38 \%$. In the process of the revision of oriented personnel training program, the idea of experting in one thing and good at many is mainly reflected in the core curricula and practice oriented courses. The reform should be based on these courses, construct modular curriculum systems, and adopt related measures and strategies. Main courses, including "Pre-school Hygienic" "Pre-school Pedagogy" "Psychology of Child Development", primarily aim at building the most important professional quality. On this basis, with the emphasis on the abilities of special education, module course, like inclusive education teaching courses, include "Special Pedagogy" "Behavior Modification" "Psychological Consultation" "Sign Language" "Sensory Integration Training". Early education module course focuses on cultivating the abilities of 0-3 years education, including "Infant Children Development and Nursing" "Parenting Skills" "Service Agencies for Early Education". 


\subsection{Formation of Curriculum System with Integration of Teaching, Learning and Practice}

By the social demand and individual desire, curriculum system includes compulsory module, such as general courses, professional skill courses, professional theory courses, and practical orientation elective module. Integration of teaching, learning and practice will make the ability of sustainable development prominent. This system will help students to integrate theory with practice; students enhance the agility and the ability to solve practical problems. Helping the students' complement of connecting theory with practice is very important in curriculum implementation. For this purpose, it is importance to optimize learning process with segments, for instance multi-media teaching, inspect and learn from practice, simulation teaching and case study. Adopt this practice; students can travel between colleges and kindergarten, and from imitation to transcend, from obedience to question, to reconstitute cognition process of teacher-to-be. And it is in favor of building work experience and abilities structure.

The learning process optimizing needs to break through teaching time and space limitations open up new ways to outside of the colleges and universities. Industry experts provide guidance whole course. The cultivation of normal students will transform from normal education with "teacher-teaching, students-learning" method, to teacher education with experiential learning models.

In addition, to ensure the practice learning process, we need to project a number of kindergartens in many different regions for integrated practical activities.

Therefore, curriculum system is aimed at meeting the needs of child education in talent training. After that, curriculums for cultivating kindergarten teacher will be integrated in several levels.

\subsection{Optimize Curriculum Content around Professional Ability Promotion}

A case study of special education abilities cultivation, the ideas of optimizing existing courses is to create the model of abilities firstly. So, summarized by practice it is very clear that the ability of providing learning support for all children needs syncretism career competency. Secondly, we have two ways. One is to integrate original courses content. For example, "Pedagogy" includes special educational section; "Psychology" includes some content of psychology of child development. Basis on normal courses, course dedicated to help students master the abilities of differentiated instruction, cooperative instruction, diagnosing and evaluating, behavior modification will be added in. This curriculum system design can help them face the challenge.

On the principle of promoting penetration with ability, the other is to create curriculum group, centered on professional abilities. Professional knowledge and idea, teacher's ethics will be throughout the curriculums. Learning concept around the practice will be established. Additionally, to improve the inner structure validity, we need to restructure every course, except some necessary crossed contents.

\subsection{Build Perfect Security System of Teaching Quality}

The teaching material and resources integrated context, principle and cases should be strengthened. Resourceful learning activities can improve the actual effect of cooperative education and communication practices base. Accordingly, we need to build curriculum and teaching assessment system, to lay emphasis on process-oriented assessment, to set up performance appraisal system. To ensure the leading edge, timeless and pertinence, the teaching group should consist of famous teachers and industry experts.

On the one hand, the problem in curriculum reform practice of kindergarten will be researched as topic of pedagogic research. Based on advantage of preschool education and research, we can explore the model of growing tighter with the bases. These topics of study will be transforming into research projects by discussion between teacher and students. So, teaching and research are 
promoting each other. On the other hand, the research projects by commission from practices base will improve teaching quality, and lead the preschool educational reform.

\section{Conclusions}

With the progress of the times, the field of early childhood education obtains more and more attention. This situation means the requirements. The teacher will no longer only be a transfer of human civilization, but a supporter, helper for child's learning.

The children are builders of their own knowledge and experience. Accordingly, the teachers become to pay attention to how to learning. Then, colleges and universities are required to transform their ideas and cultivate innovative talents, and applied talents. The normal idea in cultivating talents, just as "meet change with constancy" must be changed.

If the aim and process of cultivating talents on supply-side obtain adjustment, it will improve the actual effect of colleges, then college will become reservoir of early childhood education. If leading role of college in education and research comes to play, excellent talents supplication will drive the education quality.

It should be noted that the supply-side reform is not everything. The education administrative department and university administrations shouldn't expect to solve all problems in the development with supply-side reform. Start from their own advantages, they should be clear on what problems can be solved with supply-side reform, firstly. Then, they can determine the development goals, clear the development idea in the future, and promote supply-side reform. Especially, based on regional economic environment, colleges and universities should try their best to get development resources, change school-running orientation and thought, and deepen supply-side reform to find the efficient approach.

\section{Acknowledgements}

The article is a part of results of undergraduate teaching reform and universities of Shandong province in 2015(NO:2015M215)

\section{References}

[1] Min Yu, Study on Cultivation Students on Preschool Education Major in Colleges and Universities. Education and Career,2013, (35), 81-82.

[2] Niu Jinfang, Discussion on Preschool Teacher Education Curriculum System. Education Research,2013, (10)45-48.

[3] Qiao Chunhua, Reform on Supply-side and Progress of Higher Education. Journal of Huaihai Normal University,2016,(2),113-117.

[4] Xia Jizhou, Study on Enterprise Education in Colleges Based on the Reform on Supply-side. Shandong Youth Political College Journal, 2016,(3), 69-72.

[5] Su Xiaoyan, Reform on Supply-side and Transformation of Local Universities. China Higher Education, 2016,(10),31-32.

[6] Ren Jiru, Study on the Innovative and Entrepreneurial Talents Training Mode of the Applied Technical College in the Supply Front Reform. Journal of Higher Education, 2016,(19),191-192.

[7] Li Yuanhao, Research on Innovative and Entrepreneurship Education in Colleges and Universities under the Background of Supply-side Reform. Theory Exploration, 2016, (10),47-49.

[8] Cheng Shuqiang, China's Higher Education Reform: a Perspective of the Supply Side Reform. Journal of National Academy of Education Administration, 2016,(8),12-16. 